Ministry of Mines, including Garland, 1972, the geology of sheet ND 37-7, though recently publication of maps (1) 1:250000 scale of the geology of sheet ND37-11, compiled by Dr Beyth, and (2) 1:2000000 scale of the geology of Ethiopia compiled from many sources in 1973 by Mr V. Kazmin, has shown for the first time the place of the Tigre 'upper complex', equivalent to the Tsaliet and Tambien groups (Beyth, 1971), in the geological structure of the entire country.

It is to be hoped that Dr Beyth's own recent results on his field work of previous years in Tigre province will be available to all those interested in the Geology of Ethiopia.

South Hall

C. R. GARLAND

Castle Hill

Guildford, Surrey

31 st October 1973

\title{
The boundary between the Wenlock and Ludlow Series
}

SIR - The problem of recognizing the junction between the Wenlock and Ludlow Series in terms of the graptolite zones, which arises from the lack of conclusive graptolite evidence in the upper part of the Wenlock Limestone and Lower Elton Beds in the type areas of the two Series, has been discussed by Holland, Rickards \& Warren (1969, pp. 679-81). They have recommended on the evidence available that the base of the nilssoni Zone should be taken as the base of the Ludlow Series in the graptolitic facies (p. 681). This view was reiterated by Cocks et al. $(1971$, p. 105).

The problem remains, however, whether in the type area of the Ludlow Series at Ludlow the base of the nilssoni Zone (a) coincides precisely with the base of the Eltonian i.e. the base of the Ludlow Series as accepted by successive authors following Holland, Lawson \& Walmsley (1963) or (b) occurs above this horizon either within or at the top of the Lower Elton Beds or (c) occurs below it, either within the Wenlock Limestone or Tickwood Beds. These possibilities have been discussed by Lawson (1971, pp. 305-6).

Outside the Ludlow district, Holland et al. (1969, p. 678) report the presence of Monograptus varians Wood in the Lower Elton Beds of the Malverns, Monograptus uncinatus orbatus Wood in the Lower Elton Beds of May Hill, and Pristiograptus dubius? (Suess) together with $M$. cf. varians varians in the Lower Elton Beds of Millichope, Shropshire. To these records may be added those of Monograptus cf. unguiferus Perner and $M$. cf. uncinatus orbatus (identifications by Dr P. T. Warren) from the Tresglen Beds (lowest Ludlow Series) of the Llandeilo district (White 1969, p. 96). Each of these faunas provides evidence of the nilssoni Zone, but because the Lower Elton Beds of these areas may not be coeval with those of the type area, these occurrences cannot be taken as conclusive evidence of a nilssoni Zone age for the Lower Elton Beds in the Ludlow district.

The purpose of this letter is to report that during the recent survey of the Telford New Town area by the Institute of Geological Sciences a well-preserved example of Monograptus uncinatus orbatus (identification confirmed by Dr Warren), registered number GSM DEX8256, associated with a rich shelly fauna of low Eltonian aspect, was collected at an exposure of Elton Beds $1 \mathrm{~km}$ NE of Much Wenlock, Shropshire [NGR SJ 6302 0069]. Taking account of the regional dip of the strata, Mr B. C. Coppack, Institute of Geological Sciences, who surveyed the area, estimated that the horizon from which the graptolite was collected lies only 3-5 $\mathrm{m}$ above the Wenlock Limestone, though the outcrop of the Wenlock Limestone lies $200 \mathrm{~m}$ to the W.

$M$. uncinatus orbatus has a limited stratigraphical range, being restricted to, and characteristic of the lower part of, the nilssoni Zone (Warren, 1971, p. 453). Thus this 
record significantly reduces the thickness of strata of uncertain age in terms of the graptolite zones at the Wenlock-Ludlow Series boundary in the type area for the Wenlock Series. But being outside the type area (Ludlow) of the Lower Elton Beds, no unequivocal conclusion can be drawn from this new record regarding the graptolite zone to which these Beds should be assigned. However, taken in conjunction with the earlier records, it significantly increases the probability that the base of the Ludlow Series in its type area as defined at Pitch Coppice by Holland et al. (1963, p. 139 and fig. 11) lies at the lower limit of the nilssoni Zone.

\section{References}

Cocks, L. R. M., Holland, C. H., Rickards, R. B. \& Strachan, I. 1971. A correlation of Silurian rocks in the British Isles. Q. Jl geol. Soc. Lond. 127, 103-36.

Holland, C. H., Lawson, J. D. \& Walmsley, V. G. 1963. The Silurian rocks of the Ludlow district, Shropshire. Bull. Br. Mus. nat. Hist. (Geol.) 8, 93-171.

Holland, C. H., Rickards, R. B. \& Warren, P. T. 1969. The Wenlock graptolites of the Ludlow district, Shropshire, and their stratigraphical significance. Palaeontology 12, $663-83$, pl. 130.

Lawson, J. D. 1971. Some problems and principles in the classification of the Silurian System. Mém. Bur. Rech. géol. min. 73, 301-8.

Warren, P. T. 1971. The sequence and correlation of graptolite faunas from the WenlockLudlow rocks of North Wales. Mém. Bur. Rech. géol. min. 73, 451-60.

White, D. E. 1969. In: A. Rep. Inst. Geol. Sci. $(G B)$ for 1968, 96.

Palaeontology Department

DENNIS E. WHITE

Institute of Geological Sciences

Exhibition Road

London SW7 2DE

9th April 1974

\section{Ardnamurchan, Centre 1}

SIR - The recent letter by Green \& Wright (1974) reiterates their misgivings about the geological history of Ardnamurchan, in particular that the Ben Hiant vent is early yet topographically low compared with the high elevation of the later gabbroic plutonic centres. This geological relationship is, however, not unusual; an analogy exists in Skye between the Kilchrist vent south of Broadford and the Cuillen plutonic centre.

They ask (p. 164) where are the intervening faults which give this contrast in elevation? The answer lies partly in the numerous cone-sheets each of which lies along an inclined fracture with down-throw outwards from the centre, and partly in the fact, evidenced by the intrusive Ben Hiant dolerite, that only some of the lower harizons of the pyroclastic beds filling the crater are preserved. In addition, any postulated cauldron subsidence within the vent merely enhances the above topographic contrast, and there is some evidence for this (Richey \& Thomas, 1930, p. 124). It has been shown (Le Bas, 1971) that cone-sheets are capable of raising the country rocks constituting the inner conical portions relative to their surroundings. In Ardnamurchan the central area has been raised by about a hundred times as many cone-sheets as has Ben Hiant and thus, contrary to Green \& Wright's interpretation (p. 163, 1. 13), Ben Hiant has been relatively lowered by the cone-sheets in comparison with the country rocks in which the 